\title{
PROTECTIVE EFFECT OF CARNOSINE ON AMIKACIN-INDUCED NEPHROTOXICITY IN RATS
}

\author{
BY \\ *Mohamed A. M. Khalaf, **Sherin S. Ghaleb and *Mohamed F. Abbas \\ Dept. of Forensic Medicine and Clinical Toxicology \\ Faculty of Medicine , *El-Minia University, **Cairo University
}

\begin{abstract}
The current work was conducted to study the possible protective effect of carnosine on nephrotoxicity induced by amikacin in rats. Eighty adult male albino rats were allocated into four groups (20 animals each) and were injected daily for 2 weeks as follows: Group I: injected with $1 \mathrm{ml}$ isotonic saline; Group II: injected with carnosine (10 mg/kg); Group III: received amikacin (30 mg/kg); Group IV : animals were simultaneously treated with carnosine and amikacin with the previously mentioned doses respectively. Blood samples were obtained for biochemical analyses. Then, rats were decapitated and the kidneys were collected for histopathological study. Results: amikacin administration induced elevation of blood urea and serum creatinine concentrations while carnosine treatment did not affect those parameters. Simultaneous administration of carnosine with amikacin significantly attenuated the impairment of renal function. Conclusion: it could be concluded that carnosine may be useful for reducing the nephrotoxic effects of amikacin.
\end{abstract}

Keywords: Carnosine, Amikacin, BUN, Creatinine, Renal histopathology.

\section{INTRODUCTION}

Aminoglycosides have long been touted as beneficial antibiotics in preventing Gram-negative infections. Despite all their beneficial effects, such as high antibacterial efficacy, rapid onset of action, low rate of true resistance, synergy with $B$ lactam antibiotics and low cost (Begg and Barclay, 1995) aminoglycosides have considerable nephrotoxic side effects that have been documented in numerous species of experimental animals (Klein et al., 1992; Ibrahim et al., 1994).
One mechanism of this toxicity from aminoglycosides is believed to involve the generation of reactive oxygen radical species; these agents likely account for the pathophysiology of aminoglycoside-induced nephrotoxicity (Baliga et al., 1998; Rao et al., 1999; Ozbek et al., 2000; Naidu et al., 2000; Parlakpinar et al., 2005).

Carnosine is a biological di-peptide predominating in long lived tissues such as skeletal muscle and brain (Hipkiss and Chana, 1998). It is an antioxidant which stabilizes and protects the cell membrane. 
Many antioxidants aimed to prevent free radicals from harmfully oxidizing tissues. However, most antioxidants have no effect after the first line of defense is broken (Hipkiss et al., 1997).

As antioxidants could be useful in reducing the nephrotoxicity of aminoglycosides, the current work was conducted to study the possible protective role of carnosine on amikacin-induced nephrotoxicity in rats.

\section{MATERIAL AND METHODS}

\section{Animals :}

Eighty adult male albino rats with an average weight of 200 grams were allocated into four groups of 20 animals each as follows:

Group I (Negative control group): Animals were injected with $1 \mathrm{ml}$ isotonic saline as a daily subcutaneous dose for 2 weeks.

Group II (Positive control group): Animals were injected with a daily subcutaneous dose of carnosine "10 $\mathrm{mg} / \mathrm{kg}$ " for 2 weeks (Soliman et al., 2002).

Group III (Amikacin group): Animals were injected with a daily subcutaneous dose of amikacin "30 mg/ $\mathrm{kg}$ " double the therapeutic dose (Brunton et al., 2006) for 2 weeks.
Group IV (Carnosine-Amikacin group): Animals were simultaneously treated with carnosine and amikacin with the previously mentioned doses for 2 weeks.

\section{Drugs :}

Carnosine was obtained as ampoules produced by MEPACO, Egypt.

Amikacin was obtained as amikin ampoule produced by Bristol-Myers Squib Company, Egypt.

At the end of the experiment, the animals were fasted overnight (12-14 hs). Heparinized blood samples were obtained for separation of plasma to make biochemical analyses. Then, the rats were decapitated and the kidneys were collected for histopathological study.

\section{Chemical analysis:}

Serum levels of blood urea nitrogen (BUN) and Creatinine were determined using the Olympus Autoanalyser (Olympus Instruments, Tokyo, Japan).

\section{Histopathological studies:}

The kidneys of each animal were removed. Small pieces of fresh tissue were fixed in 10\% neutral formalin and processed. Paraffin sections $5 \mu \mathrm{m}$ thick were stained with hematoxylin and eosin. The 
histopathological changes were evaluated in several sections from each group.

\section{Statistical analysis}

Student's-t test was used for the evaluation of statistical significance. Difference was considered significant at $\mathrm{P}<0.05$ level. All values were expressed as mean \pm SD.

\section{RESULTS}

Regarding the biochemical study, amikacin administration induced significant increases of blood urea and serum creatinine concentrations in amikacin group. On the other hand, these 2 parameters were not affected by carnosine treatment. Furthermore, simultaneous administration of carnosine with amikacin significantly attenuated the impairment of renal function (Table 1 \& Fig. 1). Indeed, the increases of plasma urea and creatinine concentrations were significantly reduced in this group compared to amikacin group.

Histopathological examination of the renal sections in groups I and II revealed normal glomeruli united by little connective tissue (Figs. 2, 3). On the other hand, group III showed glomerular congestion and loss or narrowing of Bowman's space. Some glomeruli were deformed in shape. In other glomeruli, there was widening of Bowman's space. There was also partial loss of basement membrane of Bowman's capsule. Other glomeruli showed degeneration and loss of their cells with haemorrhagic areas. The convoluted tubules showed cloudy swelling of their lining epithelium with narrowed lumens. In addition, there were necrotic changes in the form of pale cytoplasm, karyolysis and pyknosis in their epithelial cells. There were numerous haemorrhagic areas in between the tubules and partial loss of the basement membranes with loss of brush borders of the tubules. There was cellular infiltration in some segments of the cortex near the glomeruli. There were periglomerular and peritubular connective tissue thickening. Some collecting tubules showed necrotic and degenerative changes in the form of pale cytoplasm, pyknosis and karyolysis. There were small numerous haemorrhagic areas in between tubules. The tubules showed partial loss of their basement membranes (Figs. 4-7). There were intertubular spaces denoting edema. The collecting tubules showed swollen epithelial cells with narrowing or obliteration of their lumens (Fig. 8).

Histopathological examination of the renal sections of Group IV (carnosineamikacin group) revealed some normal glomeruli with intact basement membranes of their Bowman's capsules. Other glomeruli were deformed. The convoluted tubules showed intact basement membranes. However, there was cloudy swelling of the lining epithelium of some con- 
voluted tubules with narrowed lumens. The collecting tubules in renal medulla showed normal histological structure (Figs. 9, 10).

\section{DISCUSSION}

Aminoglycosides nephrotoxicity, functional and morphological, is well established. Amikacin has proved to posses serious nephrotoxic side effects which may end in acute renal failure. Moreover, it was reported that amikacin-induced nephrotoxicity was not significantly dependent on dosing frequency and one injection of 1 gm was followed by extensive renal damage with severe alteration of the renal function (Sweileh, 2009).

It was early believed that the nephrotoxicity results from retention and accumulation of aminoglycosides in the proximal tubular cells (Aronof et al., 1983). In addition, Schnackenberg (2002) reported that the free radicals are responsible for the enhanced vascular tone and tubuloglomerular degeneration of the kidney which is the pathogenesis of the oxidative stress associated with diabetes mellitus, hypertension and aminoglycosides nephrotoxicity.

It is well established that some agents such as aminoglycosides generate free oxygen radicals, leading to an increased oxireductase production, which in turn in- creases tissue toxicity (Parlakpinar et al., 2003). Nowadays, it has been beleived that aminoglycosides-induced nephrotoxicity is not a simple process, and that many mechanisms are involved including increased urinary losses of carnitine (AlShabanah et al., 2010).

Carnosine, an antioxidant, was shown to be an important protective factor in human diabetes (Janssen et al., 2005) and to have curative action on hypercholesterolemia-induced kidney insult which were proved to be a consequence of oxidative stress (Soliman et al., 2004).

As amikacin-induced nephrotoxicity may be the consequence of oxidative stress and so antioxidant agents could be useful in reducing amikacin nephrotoxicity. Based on this concept, the current study was conducted to evaluate the protective effect of carnosine in amikacininduced nephrotoxicity in a rat model.

The results of the present study revealed that there was a biochemical alteration of measured renal function tests and morphological changes, including glomerular, tubular epithelial alterations and interstitial edema, in amikacin-treated rats. These findings are in agreement with many previous studies which reported that patients developed nephrotoxicity when they administered aminoglycosides for long duration and when they received 
large total dose of aminoglycosides (Chambers, 2001; De Jager and Van Altena, 2002; Wiland and Szechcinski, 2003; Parlakpinar et al., 2006).

On the other hand, the coadministration of carnosine with amikacin in the experimental animals was accompanied by marvelous improvement of the levels of BUN and serum creatinine. This is in accordance with Parlakpinar et al. (2006) who established that administration of antioxidants before amikacin injection caused significant improvement in function of the kidney compared to rats treated with amikacin alone. This was confirmed by Brunton et al. (2006) who stated that the impairment in renal function is almost always reversible because the proximal tubular cells have the capacity to regenerate.

Histopathological examination of renal sections in group IV showed that the majority of the glomeruli were normal in structure with intact basement membranes of their Bowman's capsules. The convoluted tubules have intact basement membranes and thin peritubular connective tissue. Some convoluted tubules were ballooned and have pale cytoplasm. The collecting tubules of the renal medulla were normal, although ballooning was seen in few cells. These findings are supported by the previous studies which reported that the addition of antioxidants with aminoglycosides therapy attenuates the renal damage and protects the kidney from the oxidative degenerative changes (Chen and Tappel 1995; Pedraza-Chaverri et al., 2003; Mehri et al., 2005).

The protective ability of carnosine could be explained by the following mechanisms: first, it was proved that carnosine preserves the membrane fluidity (Rusakov et al., 1993). Second, it had cytosolic buffering action (Quinn et al., 1992). Third, it ameliorates the toxic decrease of antioxidants like glutathione, catalase, and superoxide dismutase (Soliman and Saba-El Rigal, 2004), and finally it acts as an efficient reactive oxygen species (ROS) scavenger (Swearengin et al., 1999).

Uniquely, carnosine was proved to posses a double antioxidant action; scavenging ROS, preventing lipid peroxidation of cell membranes, and regaining those already oxidized (Hipkiss and Chana, 1998). It is to be mentioned that, except carnosine, no other antioxidant was proved to have the ability to regain the already oxidized lipids.

On the other hand, carnosine was reported to selectively stimulate proteins and enzymes (Soliman and Ali, 2004), which in turn may produce direct effects on many cellular enzymes (Kuleva and Zalesova, 2000). In addition, it preserves protein functional properties via 
preventing the combination of deleterious radicals with protein molecules as well as removing already formed harmful protein products by forming non-functional protein-carbonyl-carnosine complexes which are gotten rid of by lysosomes (Hipkiss et al., 2002). Furthermore, carnosine was proved to have an immunostimulatory action with increased natural immune response via stimulating the growth factors and cytokines, which promotes tissue recovery (Hobart et al., 2004). Moreover, it was also reported that carnosine has an anti-inflammatory effect by its ability to suppress histamine release from mast cells, which is a part of the inflammatory reaction. Protecting the cells from the deleterious transformation of both lipids and protein molecules, carnosine could preserve molecular cell constituents and organelles thus, decreasing apoptosis (Hipkiss et al., 2002).

In conclusion, carnosine could be useful for reducing the nephrotoxic effects of amikacin. Further studies are needed to elucidate the mechanisms of protective effect of carnosine. 
Table (1): The effects of amikacin (AK) administration on the renal function of different animal groups.

\begin{tabular}{|l|c|c|}
\hline \multicolumn{1}{|c|}{ Groups } & BUN (mg/dl) & Cr (mg/dl) \\
\hline I- Control & $19 \pm 0.6$ & $0.51 \pm \mathbf{0 . 0 3}$ \\
\hline II- Carnosine & $19 \pm 0.4$ & $0.50 \pm 0.06$ \\
\hline III- Amikacin & $43 \pm 3.5 *$ & $1.12 \pm \mathbf{0 . 0 9 *}$ \\
\hline IV- Carnosine+amikacin & $24 \pm \mathbf{5 . 1}$ & $\mathbf{0 . 6 1} \pm \mathbf{0 . 0 7}$ \\
\hline
\end{tabular}

$* \mathrm{p}<0.05$ versus control; $\bullet \mathrm{p}<0.05$ versus amikacin.

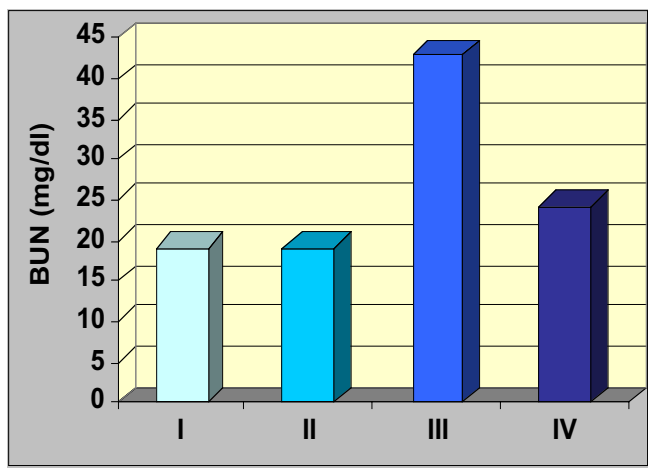

(A)

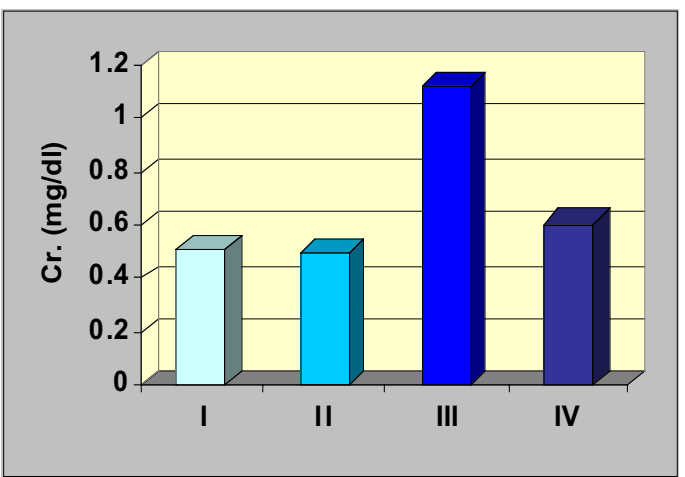

(B)

Fig. (1): Blood Urea Nitrogen [A] and serum creatinine [B] of different animal groups. 


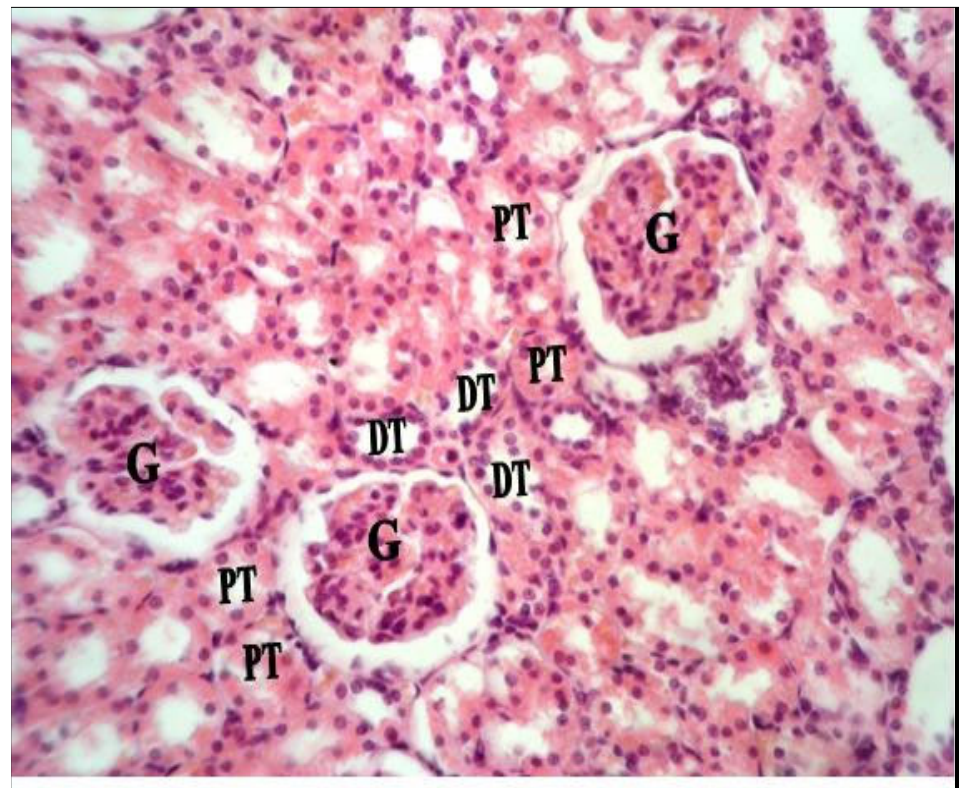

Fig. (2): Light micrograph of a section in the renal cortex of an albino rat of control group, showing normal glomeruli $(\mathrm{G})$ and normal proximal convoluted tubules (PT) and distal convoluted tubules (DT).

(H.\& E.x 400)

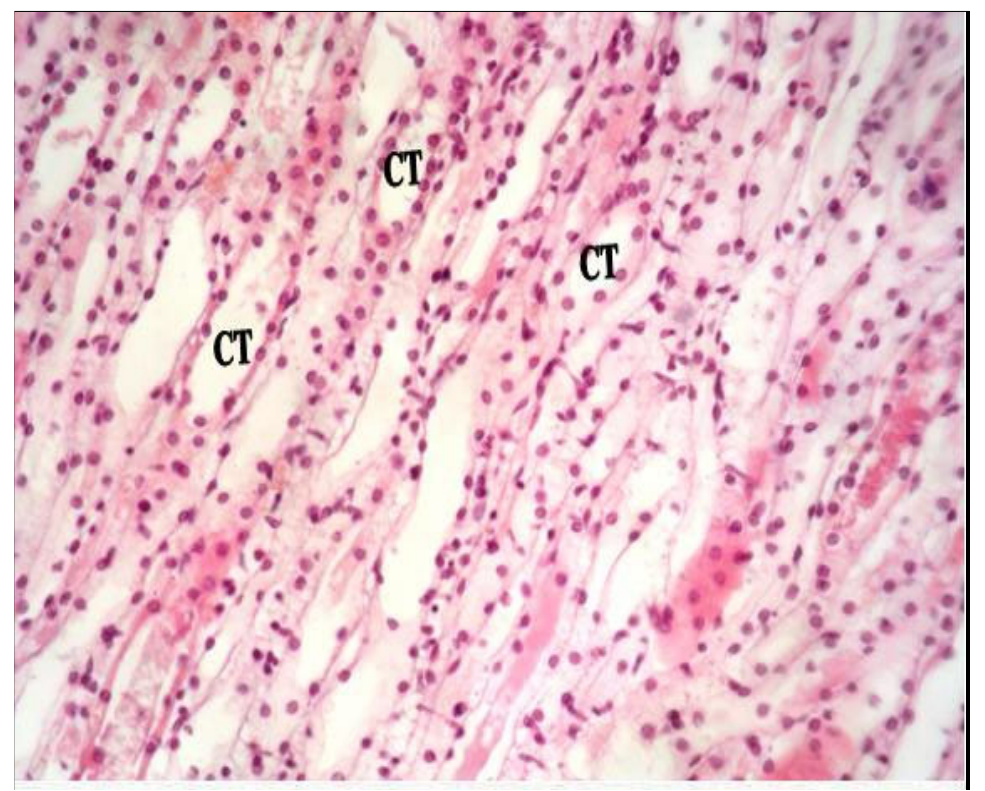

Fig. (3) : Light micrograph of a section in the renal medulla of an albino rat of control group, showing normal collecting tubules (CT).

(H.\& E. x 400) 


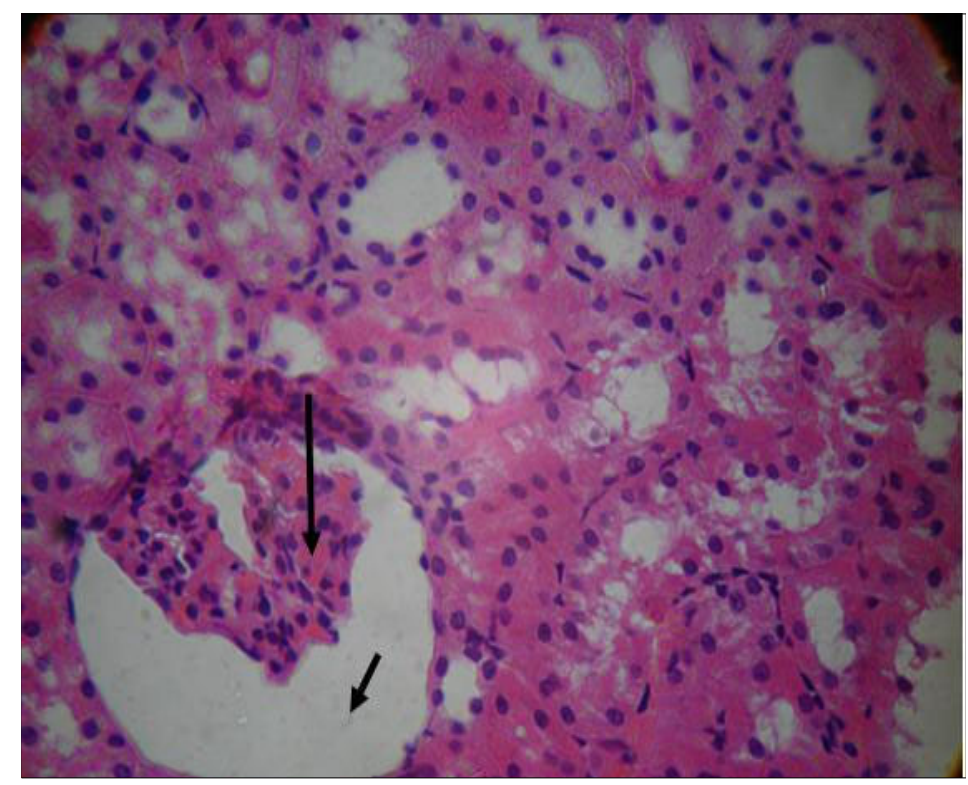

Fig. (4): Light micrograph of a section in the renal cortex of an albino rat of group III, showing glomerular congestion (long arrow) and widening of Bowman's space (short arrow).

(H.\& E.x 400)

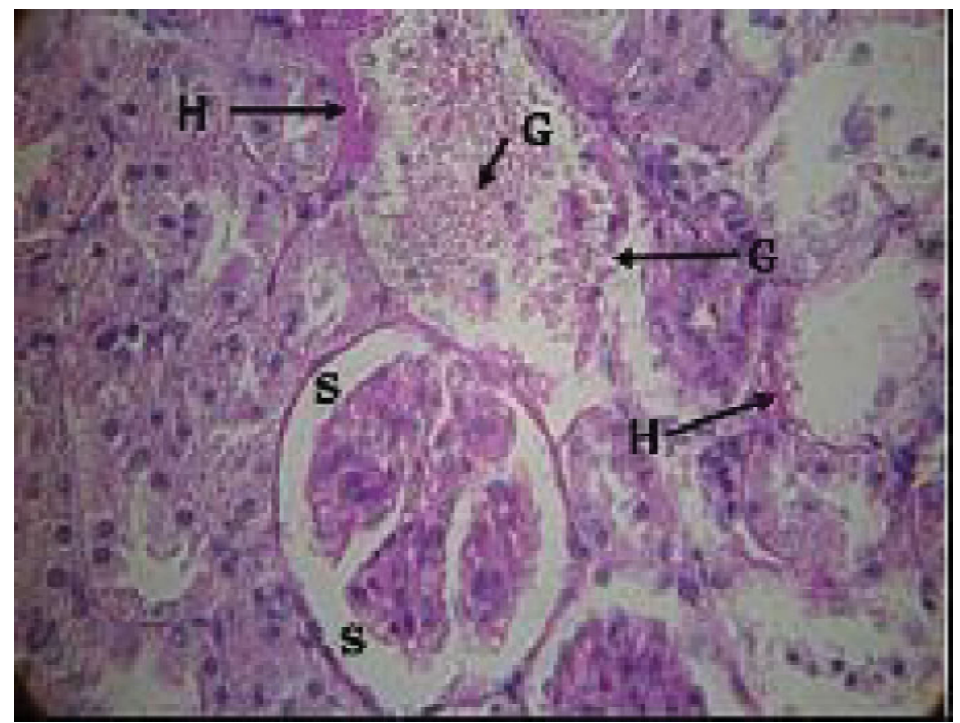

Fig. (5): Light micrograph of a section in the renal cortex of an albino rat of group III, showing loss of Bowman's space (S) and deformed glomeruli $(\mathrm{G})$. Note the convoluted tubules become ballooned and obliterated lumens with pale cytoplasm (short arrows). There are numerous haemorrhagic areas in between tubules $(\mathrm{H})$.

(H.\& E. x 400) 


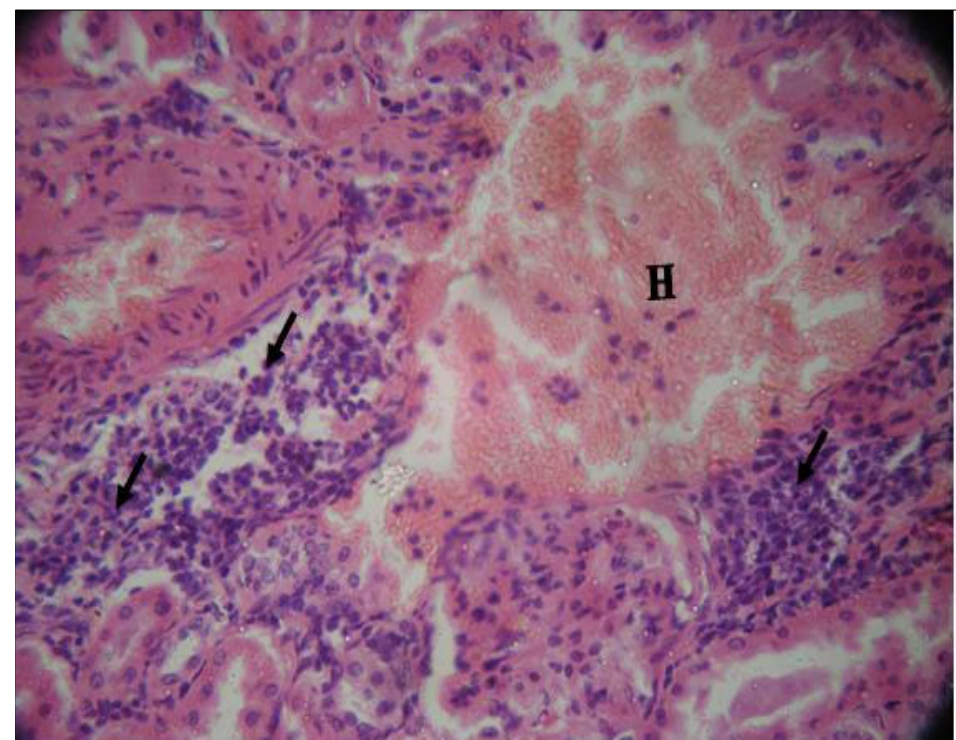

Fig. (6): Light micrograph of a section in the renal cortex of an albino rat of group III, showing cellular infiltration in some segments of the renal cortex near the glomeruli (short arrows) and haemorrhagic areas (H).

(H.\&E.x 400)

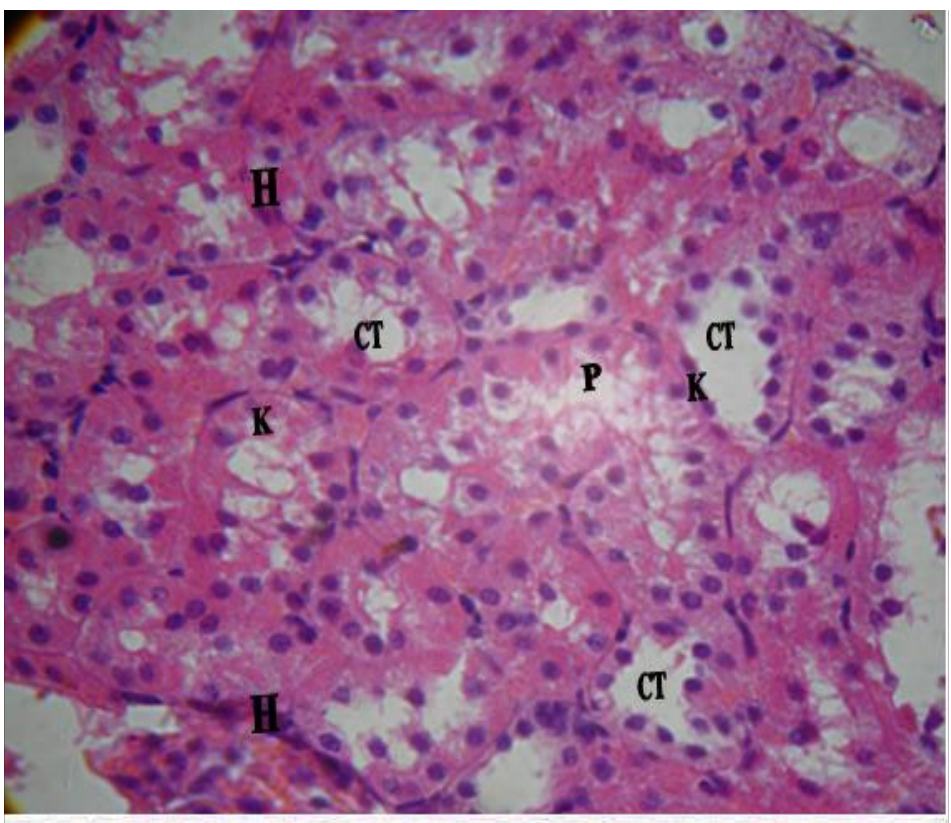

Fig. (7): Light micrograph of a section in the renal medulla of an albino rat of group III, showing necrotic changes in the collecting tubules in the form of pale cytoplasm, pyknosis $(\mathrm{P})$ and karyolysis $(\mathrm{K})$ and haemorrhagic areas in between tubules $(\mathrm{H}) . \quad$ (H.\& E.x 400). 


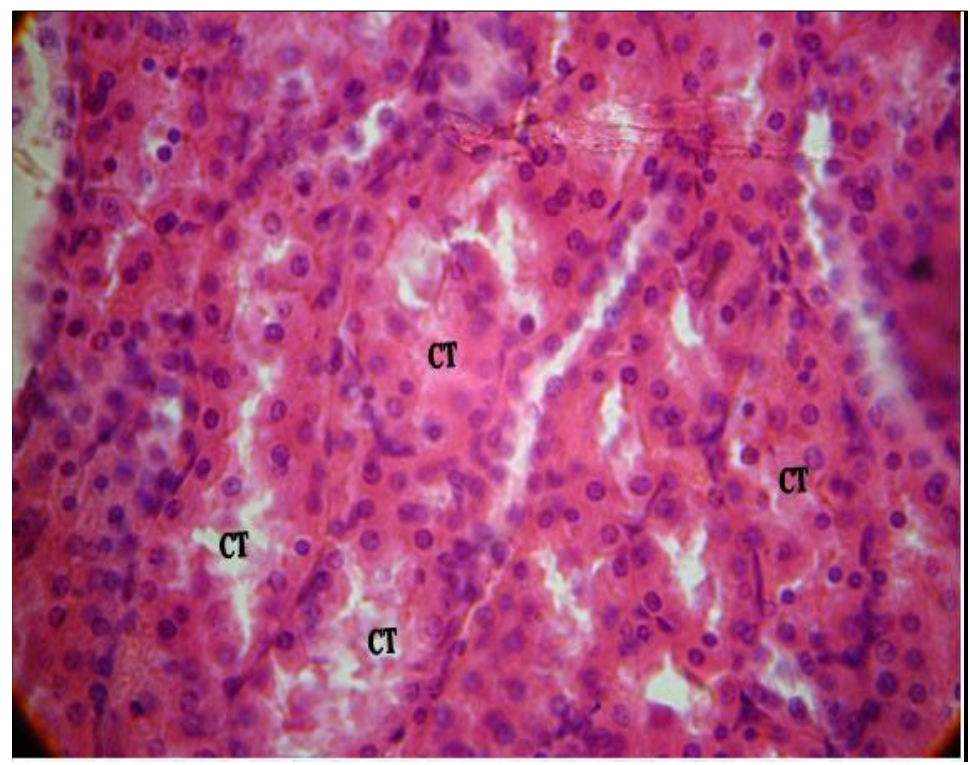

Fig. (8): Light micrograph of a section in the renal medulla of an albino rat of group III, showing narrowing and obliteration of collecting tubules (CT).

(H.\& E.x 400)

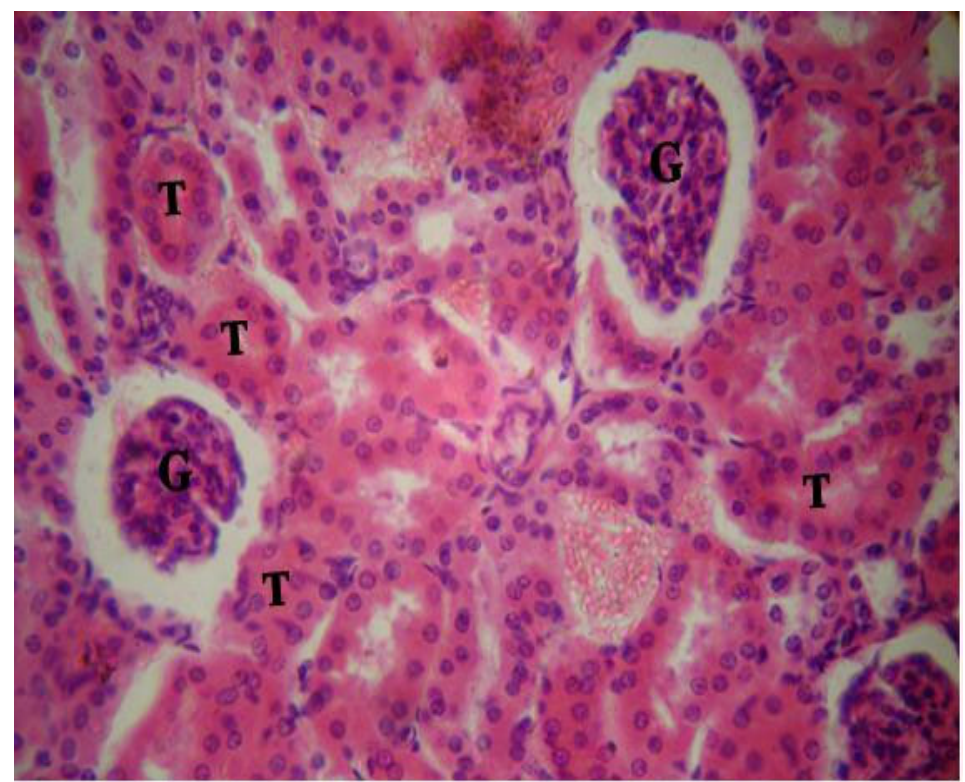

Fig. (9) : Light micrograph of a section in the renal cortex of an albino rat of group IV, showing normal glomeruli $(G)$. Some convoluted tubules $(T)$ showed cloudy swelling of their lining epithelial cells with narrowing lumens.

(H.\& E.x 400). 


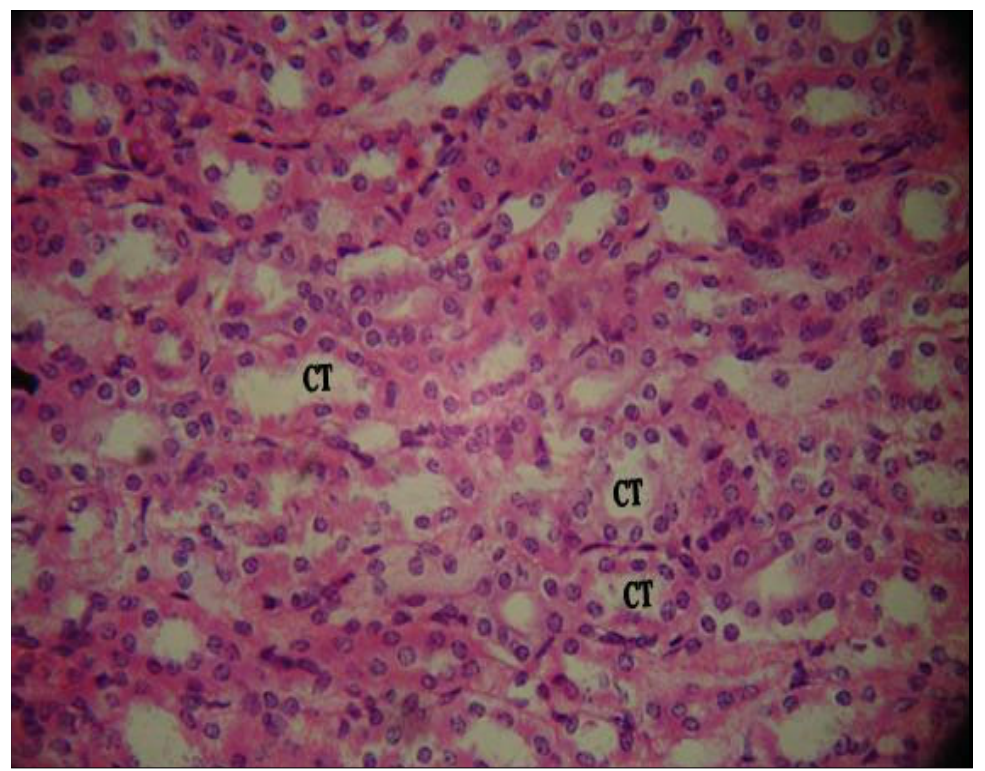

Fig. (10): Light micrograph of a section in the renal medulla of an albino rat of group IV, showing normal collecting tubules (CT). (H.\& E.x 400). 


\section{REFERENCES}

Al-Shabanah, O. A.; Aleisa, A. M.; AlYahya, A. A.; Al-Rejaie, S. S.; Bakheet, S. A.; Fatani, A. G. and Sayed-Ahmed, M. M. (2010) : "Increased urinary losses of carnitine and decreased intramitochondrial co-enzyme $\mathrm{A}$ in gentamicin-induced acute renal failure in rats". Nephrol. Dial. Transplant., 25(1):69-76.

Aronof, G. R.; Pottratz, S. T. and Brier, M. E. (1983) : "Amino-glycoside accumulation kinetics in rat renal parenchyma". Antimicrob. Agents Chemother., 23 : 7478.

Baliga, R.; Zhang, Z.; Baliga, M.; Ueda, N. and Shah, S. V. (1998) : "In vitro and in vivo evidence suggesting a role for iron in cisplatin induced nephrotoxicity". Kidney Int., 53: 394.

Begg, E. J. and Barclay, M. L. (1995) : "Aminogycosides 50 years on". Br. J. Clin. Pharmacol., 39: 597-603.

Brunton, L. L.; Lazo, G. S. and Parker, K. L. (2006) : In : Goodman \& Gilman's. The Pharmacological Basis of Therapeutics. Mc Graw-Hill Inc., 11 th ed. , P.P.11551167.

Chambers, H. F. (2001) : Aminoglycosides and spectinomycin. In: Basic and Clinical Pharmacology. Katzung B.G., Uni- versity of California, San Francisco, $8^{\text {th }}$ ed., P.P. 784-792.

Chen, H. and Tappel, A. L. (1995) : "Vitamin $\mathrm{E}$, selenium, trolox $\mathrm{C}$ and beta carotene protect against oxidative damage to kidney, heart, lung and spleen". Free Radic. Res., 22(2): 177-186.

De Jager, P. and Van Altena, R. (2002) : "Hearing loss and nephrotoxicity in long term aminoglycoside treatment in patients with tuberculosis". Int. J. Tuberc. Lung. Dis., 6 (7): 622-7.

Hipkiss, A. R.; Brownson, C.; Mariana, F.; et al. (2002) : "Reaction of carnosine with aged protein: another protective process?". Ann. N.Y. Acad., 959: 285-294.

Hipkiss, A. R. and Chana, H. (1998) : "Carnosine protects proteins against methyl glyoxal mediated modifications". Biochem. Biophy. Res. Comun., 248: 28-32.

Hipkiss, A. R.; Preston, J. E.; Himswoth, D. T.; et al. (1997) : "Protective effects of carnosine against MDA-induced toxicity towards cultured rat brain endothelial cells". Neuroscience Letters, 238 : 135-138.

Hobart, L. J.; Seibel, I.; Yargans, G. S. and Seidler, N. (2004): "Anticross-linking properties of carnosine: significance of histidine". Life Sci., 30: 1379-1389. 
Ibrahim, S.; Langhendries, J. P.; Bernard, A. and Tulkens, P. M. (1994) : "Urinary phospholipids excretion in neonates treated with amikacin". Int. J. Clin. Pharmacol. Res., 14: 149.

\section{Janssen, B.; Hohenadel, D.; Brinkkoet-} ter, P.; et al. (2005) : "Carnosine as a protective factor in diabetic nephropathy". Diabetes, 54: 2320-2327.

Klein, J.; Koren, G. and McLeod, S. M. (1992) : "Comparison methods for prediction of nephrotoxicity during development". Dev. Pharmacol. Ther., 19: 80.

Kuleva, N. V. and Zalesova, Z. (2000) : "Non enzymatic glycol-sylation and oxidative damage to actin in vitro and in vivo". Tsitologiia, 42: 66-71.

Mehri, K.; Hossein, K.; Mahdieh, F.; Rana, G. and Maryam, Z. (2005) : "Effects of co-supplementation of vitamins $E$ and $\mathrm{C}$ on gentamicin-induced nephrotoxicity in rats". Experimental physiology, 90(4): 571-576.

Naidu, M. U.; Shifow, A. A.; Kumar, K. V. and Ratnakar, K. S. (2000) : "Ginkgo biloba extract ameliorates gentamicininduced nephrotoxicity in rats". Phytomedicine, 7: 191-197.

Ozbek, E.; Turkoz, Y.; Sahna, E.; Ozugurlu, F.; Mizrak, B. and Ozbek, M.
(2000) : "Melatonin administration prevents the nephrotoxicity induced by gentamicin". B.J.U. Int., 85: 742-746.

Parlakpinar, H.; Koc, M.; Polat, A.; Vardi, N.; Ozer, M. K.; Turkoz, Y. and Acet, A. (2006) : "Protective effect of amino-guanidine against nephrotoxicity induced by amikacin in rats". Cell Biochem. Funct., 24(4): 363-367.

Parlakpinar, H.; Tasdemir, S.; Polat, A.; et al. (2005) : "Protective role of caffeic acid phenethyl ester (cape) on gentamicininduced acute renal toxicity in rats". Toxicology, 207 (2): 169-177.

Parlakpinar, H.; Ozer, M. K.; Sahna, E.; Vardi, N.; Cigremis, Y. and Acet, A. (2003): "Amikacin-induced acute renal injury in rats: protective role of melatonin". J. Pin. Res., 35(2): 85-90.

Pedraza-Chaverri, J.; GonzalezOrozco, A. E.; Maldonado, P. D.; Barrera, D.; Medina-Campos, O. N. and Hernandez-Pando, R. (2003) : "Daily disulfide ameliorates gentamicin-induced oxidative stress and nephropathy in rats". Eur. J. Pharmacol., 347:71-78.

Quinn, P. J.; Boldyrevt, A. A. and Formazuyk, V. E. (1992) : "Carnosine: Its properties, functions and potential therapeutic applications". Mol. Aspects Med., 13: 379-404. 
Rao, M.; Kumar, M. M. and Rao, M. A. (1999) : "In vitro and in vivo effects of phenolic antioxidants against cisplatininduced nephrotoxicity". J. Biochem., 125: 383.

Rusakov, V. V.; Dolgikh, V.T. and Korpacheva, O.V. (1993): "The membrane protective effect of carnosine in the post resuscitation period after acute lethal blood loss". Vopr. Med. Khim., 39: 26-28.

Schnackenberg, C. G. (2002) : "Oxygen radicals in cardiovascular renal disease". Curr. Opin. Pharmacol., 2(2): 121-125.

Soliman, K. M. and Ali, H. F. (2004) : "Promoting effect of carnosine on serum proteins in normal and partially hepatectomized mice". Egypt J. Physiol., 25: 167184.

Soliman, K. M. and Saba-El Rigal, N. (2004) : "Effects of L-carnosine administration on some hepatic antioxidants after ethanol intoxication". Egypt Pharmac. J., 3: 147-158.

Soliman, K. M.; Abdel Aziz, M.; Nas- sar, Y. H.; et al. (2002) : "Effects of carnosine on bilharzial infection in hamsters; biochemical and histochemical studies". Comp. Bioch. Physiol., 131: 535-542.

Soliman, K. M.; Mohamed, A. M. and Metwally, N. S. (2004): "Hepato and renoprotective effects of carnosine and fluvastatin against hypercholesterolemic stress". Egypt Pharm.J., 3: 123-145.

Swearengin, T. A.; Fitzgerald, C. and Seidler, N. W. (1999) : "Carnosine prevents glyceraldehydes 3-phosphatemediated inhibition of aspartate aminotransferase". Arch. Toxicol., 73 : 307309.

Sweileh, W. M. (2009) : "A prospective comparative study of gentamicin- and amikacin-induced nephrotoxicity in patients with normal baseline renal function". Fundam. Clin. Pharmacol., 23 (4) : 515-520.

Wiland, P. and Szechcinski, J. (2003) : "Proximal tubule damage in patients treated with gentamicin or amikacin". Pol. J. Pharmacol., 55:631-637. 


\title{
التأثير الوقائى للكارنوزين على الاعتلال الكلوى السهى النانج عن الأ ميكاسين فى الجرذ الجنان
}

\author{
المشتركون فى البحث

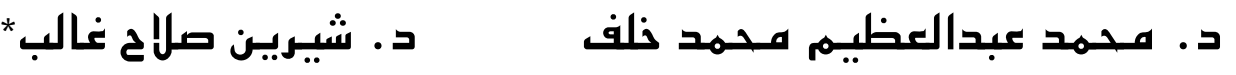 \\ כ. هـهـ فتحس عباس \\ قسـم الطب الشرعى والسموم الإكلينيكية، كلية الطب - جامعة المنيا - جامعة القاهرة*
}

تعتبر مجموعة الأمينوجلايكوزيدس من أكثر المضادات الحيوية كفاءة، غير أن الذى يحد من استخدامها بصورة واسعة وجود تأثير سمى على الكلى الأمر الذى تعزوه بعض الدراسات الحديثة إلى العوامل المؤكسدة الضارة الناتجة عن استخدام عقاقير هذه المجموعة وعلى رأسها الأميكاسين، ومن ناحية أخرى فإن عقار الكارنوزين من أكثر مضادات الأكسدة إنتشاراً وكفاءة.

وحيث أن استخدام مضادات الأكسدة يبدو من الناحية النظرية مفيداً فى منع حدوث التأثير السمى لمجموعة الأمينوجلايكوزيدس، فقد أجريت هذه الدراسة لتقييم التأثير الوقائى المحتمل للكارنوزين فى حالات الاعتلال الكلوى السمى الناتج عن الأميكاسين فى الجرذان وقد شملت الدراسة ـ ^ من جرذان التجارب البيضاء تم تقسيمهم إلى ع مجموعات (المجموعة = . ب جرذاً) على النحو التالى : المجموعة الأولى : (مجموعة ضابطة) : تم حقنها بمحلول ملحى فسيولويجى تحت الجلد ( مل) يومياً لمدة أسبوعين.

$$
\text { المجموعة الثالثة : تم حقنها بعقار الأميكاسين تحت الجلد ( ـ الم مجم / كجم) يومياً لمدة أسبوعين. }
$$

المجموعة الرابعة : تم حقنها بعقار الكارنوزين تحت الجلد ( ـ مجم / كجم) وبعقار الأميكاسين تحت الجلد ( ـ مجم / كجم) يومياً لمدة

$$
\text { أسبوعين. }
$$

بعد إنتهاء فتـرة التجربة، تم أخذ عينات من الدم لقياس مستوى اليوريا والكرياتينين، بعد ذلك تم قتل هذه الحيوانات وانتزاع الكلى لدراستها من الناحية الهستوباثولوجية.

وقد بينت نتائج الدراسة وجود ارتفاع دال إحصائياً فى مستوى اليوريا والكرياتينين فى الجرذان التى تم حقنها بعقار الأميكاسين بينما لم تتـأثر هذه المتغيرات فى الجرذان التى تم حقنها بعقار الكارنوزين، كما اتضح أن إعطاء العسارين معاً قد أدى إلى إنخفاض تأثير عقار 
الأميكاسين فى مستوى اليوريا والكرياتينين بصورة ذات دلالة إحصائية.

ومن الناحية الهستوباثولوجية، فقد كانت نتيجة الفحص المجهرى لعينات الكلى للمجموعتين الأولى والثانية طبيعية، بينما أظهر الفحص المجهرى لعينات الكلى للمجمسوعة الثالثة والتى تم حقنها بعقار الأميكاسين وجود تغيرات مرضية فى الحسويصلات والأنابيب الكلوية مع وجود إرتشاح خلوى، وبالنسبة لنتيـجة الفحص المجهرى لعينات الكلى للمجموعة الرابعة فقد كانت طبيعيـة فى الغالبية العظمى من العينات، كما لوحظ وجود تغيرات طفيفة فى بعض العينات فى صورة إنتفاخ بعض الخلايا فى الأنابيب الملتوية مع ظهور السيتـوبلازم بصورة باهتة وكذلك وجود إنتفاخ بعض الخلايا فى الأنابيب الجامعة.

ومن نتـائج هذه الدراسة والتىى أظهرت وجود تحسـن من الناحيـة الوظيفيـة والخلوية، يمكن إسـتنتـاج أن لعــار الكارنوزين دور وقـائى على الاعتلال الكلوى السمى الناتج عن الأميكاسين فى الجرذان. 